\title{
A few maxima culpas
}

Or maximae culpae. In August, I received an e-mail from colleague, friend, and ET contributor John Algeo in the United States. It ran: 'I was much interested to read in the July 1999 English Today (pp. 30-31) that the English prefer the plural "millenia" over "millenums" by better than two to one. Quite right if that's the choice. But that they should prefer "indeces" as the plural of "index" was rather a surprise. Still, de gustibus and all that, I suppose.'

When I had re-read the note I sighed. The rebuke was graceful, but rebuke it was - and entirely justified. The errors were in a table of data, part of Pam Peters's report on Langscape 4. So obvious: yet how could they have happened and why did we miss them? The answer is part-technological, part-traditional. The original table came as an accurate fax from Sydney, Australia. It came that way because faxes tend to be safer for the layout of tables than attached e-files (now the norm for submitted material). Such tables are then scanned into a computer and placed in the text. But faxes can be blurred and scanners scan what they can, and no one - designer, proof-reader, or editor - noticed the outcome on this occasion. One reason is that we knew we could trust Pam's high standards in her work, but that is no excuse.

It is chastening that of all the places where error might arise it should be in a panel on pluralizing Greco-Latin words - such fertile ground for error. It is also particularly ironic after publishing Jon Auerbach's piece on spelling and misspelling millennium (in ET52, Oct 97). O tempora, O mores, O dear.

At the present time we agonize about language education and language use, and are often polarized between descriptivism and prescriptivism. In Comment in July, I wrote about a 'new prescriptivism', the shy beginnings of a revival of 'standards' - or maybe not so shy after all, as in Brian Garner's new Dictionary of American Usage, which I look at on p. 59. But whatever the trends, for the international printed language (which is at the very heart of any debate on standards and standardness) the buck stops here, with setters, proof-readers, and editors, which is where it has always stopped. And shoudl alwyas stop.

\section{Tom McArthur}

The editorial policy of English Today is to provide a focus or forum for all sorts of news and opinion from around the world. The points of view of individual writers are as a consequence their own, and do not reflect the opinion of the editorial board. In addition, wherever feasible, ET generally leaves unchanged the orthography (normally British or American) and the usage of individual contributors, although the editorial style of the journal itself is that of Cambridge University Press. 